\title{
Effect of moisture content on some physical properties of domestic wheat
}

\author{
Oui-Woung Kim ${ }^{1}$, Hoon Kim ${ }^{1}$, Sang-Suk Kim ${ }^{2}$, Eun-Jung $\mathrm{Choi}^{1 *}$ \\ ${ }^{1}$ Division of Food Safety, Distribution and Standard Research, Korea Food Research Institute, Seongnam 13539, Korea \\ ${ }^{2}$ Division of Functional Food Research, Korea Food Research Institute, Seongnam 13539, Korea
}

\section{함수율에 따른 우리밀의 물리적 특성}

\author{
김의웅 ${ }^{1} \cdot$ 김훈 $^{1} \cdot$ 김상숙 $^{2} \cdot$ 최은정 ${ }^{1 *}$ \\ 1한국식품연구원 안전유통연구본부, ${ }^{2}$ 한국식품연구원 기능성식품연구본부
}

\begin{abstract}
The physical properties of wheat kemels were determined as a function of moisture content to optimize the design of equipment for post-harvest management. Several properties, including bulk density, dynamic repose angle, one thousand-kernel weight, specific gravity, length, width, thickness, and area of two wheat cultivars (Baekjjung: B and Jogyeong: $\mathrm{J}$ ), were studied in the moisture range from approximately $9 \%$ to $30 \%$ wet basis. As moisture increased, length increased linearly from 6.42 to $7.20 \mathrm{~mm}(\mathrm{~B})$ and 8.71 to $9.15 \mathrm{~mm}(\mathrm{~J})$, width increased from 2.90 to $3.49 \mathrm{~mm}(B)$ and 4.12 to $4.43 \mathrm{~mm}(J)$, thickness from 2.94 to $3.20 \mathrm{~mm}(\mathrm{~B})$ and 3.29 to $3.63 \mathrm{~mm}(\mathrm{~J})$, and area from 14.13 to $19.44 \mathrm{~mm}^{2}(\mathrm{~B})$ and 27.75 to $31.25 \mathrm{~mm}^{2}(\mathrm{~J})$. Additionally, the dynamic repose angle and one thousand-kernel weight increased linearly from $46.3^{\circ}$ to $54.0^{\circ}$ (B) and $46.3^{\circ}$ to $54.5^{\circ}$ (J) and from 32.26 to $41.51 \mathrm{~g}(\mathrm{~B})$ and 45.30 to $63.07 \mathrm{~g}(\mathrm{~J})$, respectively, as the moisture content increased. Based on the experimental measurements, only the bulk density and specific gravity decreased from 754.0 to $664.1 \mathrm{kgm}^{-3}$ (B) and 776.1 to $660.0 \mathrm{kgm}^{-3}(\mathrm{~J})$ and from 1.2950 to $1.2265(\mathrm{~B})$ and 1.3379 to $1.2671(\mathrm{~J})$, respectively, as moisture content increased.
\end{abstract}

Key words : physical properties, moisture content, length, bulk density, specific gravity

\section{서 론}

밀은 세계적으로 쌀, 옥수수와 더불어 중요한 식량작물 중의 하나이며, 광범위한 지역에서 잘 자라는 재배 적합성, 저장 용이성 및 영양적 우수성 등의 특징을 갖추고 있다(1). 2015년 4월 세계 밀의 생산량은 전년 대비 $1.3 \%$ 늘어난 7 억 2,645만 톤, 소비량은 $1.4 \%$ 늘어난 7 억 1,580만 톤으로 증가추세이다. 생산지역 중 미국, 캐나다, 호주에서는 감소 추세이며, 러시아, 우크라이나, 브라질 및 중국은 증가할 것으로 전망되었다(2). 우리나라의 경우, 2013년 기준으로

*Corresponding author. E-mail : Choi.Eun-jung@kfri.re.kr Phone : 82-31-780-9043, Fax : 82-31-780-9059

Received 13 July 2015; Revised 26 August 2015; Accepted 10 September 2015.

Copyright (c) The Korean Society of Food Preservation. All rights reserved.
살펴본 재배면적 $7,373 \mathrm{ha}$, 생산량 27,130 ton 및 $10 \mathrm{a}$ 당 수량 은 $368 \mathrm{~kg}$ 으로 나타났다(3).

곡물에서의 물리적 특징은 수확 후 정선, 선별, 이송, 저 장 및 가공 공정에서 기계 및 설비시설부분을 적합한 구조 로 설계하기 위한 필수항목으로 알려져 있다(4-7). Gursoy 와 Guzel(5)은 물리적 특징 중 크기 및 외형의 기하학적 특징은 수확 후 관리 중 공정시설부분에서 가장 중요한 요소 중 하나라고 보고되었고, Sahay와 $\operatorname{Singh}(8)$ 의 연구에 서도 천립중, 크기, 외형, 원형율, 안식각, 산물밀도 측정 또한 수확 후 곡물의 선별 및 정선공정에서 매우 중요한 요소로 보고되었다. 물리적 요소 중 산물밀도는 원맥의 충 실도 및 균일도를 나타내주는 지표로, 강도, 도정 및 가공 중 빵 품질에 영향을 미칠 수 있다고 보고하였고(9), 안식각 은 곡물이송시설설계에 있어서 필수적인 측정항목이라고 보고되었다(10).

국내에서 보고된 원맥에 대한 연구는 주로 우리밀과 수 
입밀 간의 천립중, 함수율, 품위, 단백질, 회분정도의 품질 비교이며, 밀가루의 경우, 주로 제분특성, 품질특성, 국수품 질 등 가공분야에 중점을 두었다. 국내연구의 주된 목적은 고품질 밀가루 생산을 위한 기초자료, 원맥 및 밀가루특성 과 가공제품 특성평가를 통해 우리밀의 소비촉진 및 생산 확대 기초자료로 활용하기 위해서 연구하였다(11-16). 최근 연구로는 우리밀 품질 향상을 위한 지역별 재배 현황 및 원맥 특성검사로 농가에서 직접 수집한 원맥의 특성 중 천립중, 산물밀도, 수분, 단백질 및 회분함량을 분석하여 우리밀의 품질 경쟁력 확보 및 소비 확대를 위한 생산농가 의 영농지도 자료수집 및 $\mathrm{D} / \mathrm{B}$ 화의 기초자료로 활용하기 위해서 연구하였다(17). 이미 보고된 원맥에 관한 연구는 주로 원맥의 물리적 및 화학적 특성분석과 밀가루의 가공분 야에 국한된 연구로 원맥의 수확 후 관리에 관련된 연구는 현재 미미하며, 함수율에 따른 물리적 항목에 영향을 미치 는 연구자료 또한 미미한 실정이다.

함수율에 따른 원맥의 물리적 특징에 관련된 국외연구는 Tabatabaeefar(6)에 따르면 이란의 원맥 5품종(Falat, Ghods, Mahdavei, Cross Alnorz, Saradari)에 대한 함수율범위 (0 22\%)에서, Karimi 등(10)도 이란의 원맥 3품종(Shiraz, Karoun, Shiroudy)을 함수율범위 $(8,12,18 \%)$ 에서 원맥의 장축길이, 단축길이, 두께, 천립중, 산물밀도, 진밀도, 안식 각 및 정지마찰계수를 각각 분석하여 함수율간의 상관관계 를 구명하였다. Al-Mahasneh과 Rababah(18)은 요르단에서 재배되는 freekeh로 알려져 있는 청밀을 9 41\% 함수율 범 위에서의 물리적 특징을 연구하여 청밀생산을 위한 정선, 가공 및 포장 공정설비설계에 도움이 되기 위해 연구하였 다, Chang과 Converse(19)은 0 30\% 함수율 범위에서 미국 품종 원맥의 산물밀도를 분석하여 적합한 공정설비설계에 도움이 되고자 연구하였다. 함수율에 따른 상관관계를 구 명한 타 곡물 연구는 잠두콩(20), 렌틸콩(21) 및 병아리콩 $(22,23)$ 의 산물밀도, 크기, 안식각 등의 물리적 항목을 연구 하였다.

본 연구의 목적은 우리밀 건조저장 등의 수확 후 관리기 술에 대한 체계적인 연구가 전무한 상태로, 적절한 모델이 없어 벼건조저장시설과 유사한 형태로 설치되고 있으며 건조저장시설을 설치한 업체 및 이를 활용하는 운영자도 전문지식이 없는 상태로 시설의 설치이후에도 산물수매에 큰 애로를 겪는 경우가 대부분으로 우리밀의 품질경쟁력향 상을 위한 연구가 절실히 필요하였다. 따라서 우리밀의 함 수율에 따른 물리적 특징을 분석하여 함수율간의 상관관계 를 구명함으로써 현재 국내밀의 수확 후 관리 중 정선, 선별, 이송, 저장 및 가공 공정에서의 적합한 설계공정을 위한 건조 저장시설 및 수확 후 관리모델개발을 위하여 연구하였다.

\section{실험재료}

\section{재료 및 방법}

본 실험에 사용된 국내산 품종은 백중밀 및 조경밀로,
백중밀은 2012년 10월 말에 파종한 후 2013년 6월 11일에 수확한 초기함수율 29.6\%(w.b.)원맥을 광주광역시 소재 한 국우리밀농업협동조합에서 $210 \mathrm{~kg}$ 정도 구입하여 실험에 사용하였다. 조경밀은 2012년 10월 말에 파종 후 2013년 6월13일에 수확한 초기함수율 28.7\%(w.b.) 원맥을 경남 합 천우리밀영농조합에서 $210 \mathrm{~kg}$ 정도 구입하여 실험에 사용 하였다.

\section{초기 함수율 $(29 \%)$ 로 수확한 밀 건조과정 전처리}

초기함수율 28 29\%(w.b.)로 수확한 백중밀 및 조경밀은 검은망천을 덮은 2 개의 트레이에 $3 \mathrm{~kg}$ 씩 충전한 다음, 벌크 건조기(HK-DO1000F, Machinery works, Hwaseong, Korea) 에서 건조온도 $50^{\circ} \mathrm{C}$ 로 건조하였으며, 단립수분계(CTR800E, Shizuoka Seiki Co., Ltd., Shizuoka, Japan)로 함수율을 측정하면서 밀의 함수율을 $3 \%$ 간격으로 8 단계 \{기준함수율 $28 \%, 25 \%, 22 \%, 19 \%, 16 \%, 13 \%, 11 \%, 9 \%$ (w.b.) 로 건조 한 후 ASABE standards 2011(24)에 의해 시료 $10 \mathrm{~g}$ 을 $130^{\circ} \mathrm{C}$ 의 온도에서 19 시간 건조하는 방법을 이용하여 최종함수율 을 측정하였다. 아래 표는 실제 측정된 함수율 및 건조에 소요되는 시간을 나타낸 것이며, 28 29\%(w.b.) 함수율을 건조하기 위해 소요된 건조시간은 각각 백중밀(15.5시간) 및 조경밀(23.0시간)로 측정되었다.

\section{산물밀도, 동안식각, 비중 및 천립중}

산물밀도는 USDA Equipment Handbook의 방법으로 Fig. 1 과 같이 산물밀도 장치(weight per bushel test apparatus, Seedburo Equipment Co., Des Plaines, IL, USA)로 호퍼에 시료를 충전하여 아래의 용기로 시료를 흘러 보내 용기에 담은 후 그 무게 값을 5 회 반복 측정하였다(25).

동안식각은 Kim 등(26) 및 Tabatabaeefar(6)와 동일한 방 법으로 측정평판이 수평면과 $0 \sim 70^{\circ}$ 범위로 조절이 가능한 측정장치의 시료틀 $(150 \times 150 \times 100 \mathrm{~mm})$ 에 시료를 충전하고, 경사 조절 레버를 손으로 천천히 돌리면서 밀이 평판위에 서 약 $1 / 4$ 정도가 미끄러지는 순간의 각을 3 회 반복 측정하 였다.

비중은 흡습을 방지하기 위하여 톨루엔(27)(60\%용액사 용, $15^{\circ} \mathrm{C}$ 에서의 비중 0.839$)$ 을 사용하여 전자비중계 (AS-220/x, Radwag Co., Radom, Poland)로 측정하였으며, 다음 식과 같이 계산하였고, 20 립씩 5 회 반복 측정하였다

$$
p=\frac{A}{A-B} \times p_{o}
$$

여기서 $\mathrm{p}$ : 비중, $\mathrm{A}$ : 공기중의 무게(g), B : 톨루엔속에서 의 무게 $(\mathrm{g}), \mathrm{p}_{0}$ : 액체의 비중

천립중은 정립 1,000 개의 낟알을 고른 후 $0.001 \mathrm{~g}$ 의 정확 도를 갖춘 저울로 중량 값을 3 회 반복 측정하였다(28). 
장축길이, 단축길이, 두께 및 면적

장축길이, 단축길이 및 면적은 정립 선별한 후 화상분석 기(KH-2200 MD3, Hirox Co., Ltd., Hackensack, NJ, USA)로 20립씩 5회 반복 측정하였다. 두께측정은 Digimatic caliper (CD-15CP, Mitutoyo Co., Ltd., Kanagawa, Japan) 밀 정립 20립씩 5회 반복 측정하였다(11).

\section{통계처리}

유의성검증을 위하여 통계분석은 Statistical Analysis System(SAS Institute Inc., Cary, NC, USA)을 이용하였으며 모든 자료는 3 회 이상 반복 실시하였다.

\section{결과 및 고찰}

함수율에 따른 산물밀도, 동안식각, 비중 및 천립중의 변화 함수율에 따른 백중 및 조경밀의 산물밀도, 동안식각, 비중 및 천립중의 변화를 살펴 본 결과는 Table 2 및 Fig. $1 \sim 4$ 와 같다. 백중 및 조경밀의 산물밀도는 함수율 약 9 30\%(w.b.) 범위 내에서 백중밀의 경우 $754.0 \mathrm{~kg} / \mathrm{m}^{3}$ 에서 $664.1 \mathrm{~kg} / \mathrm{m}^{3}$ 로 감소함을 나타내었고, 조경밀은 $776.1 \mathrm{~kg} / \mathrm{m}^{3}$ 에서 $660.0 \mathrm{~kg} / \mathrm{m}^{3}$ 으로 감소하였다. 즉, 함수율이 높을수록 산물밀도의 값은 감소추세로 측정되었고, $\mathrm{p}<0.001$ 수준에 서 유의적인 차이를 나타내었다. 또한, 1 차식으로 표현이

Table 1. Drying time \& moisture content

\begin{tabular}{ccccccccccc}
\hline \multirow{2}{*}{ Contents } & & \multicolumn{7}{c}{ Aim of moisture content (\%, wet basis) } \\
\cline { 3 - 9 } & & $9 \%$ & $11 \%$ & $13 \%$ & $16 \%$ & $19 \%$ & $22 \%$ & $25 \%$ & $28 \%$ \\
\hline $\begin{array}{c}\text { Moisture content } \\
\text { (\%, wet basis) }\end{array}$ & Baekjjung & 9.6 & 11.0 & 13.1 & 15.5 & 19.3 & 22.2 & 26.2 & 29.6 \\
\hline $\begin{array}{c}\text { Drying time } \\
\text { (hr) }\end{array}$ & Jogyeong & 10.5 & 11.7 & 14.0 & 16.5 & 20.8 & 23.3 & 25.6 & 28.7 \\
\hline
\end{tabular}

Table 2. Physical properties of wheat with respect to moisture content

\begin{tabular}{|c|c|c|c|c|c|}
\hline \multicolumn{2}{|c|}{ Contents } & \multirow{2}{*}{$\begin{array}{l}\text { Bulk density } \\
\quad\left(\mathrm{kg} / \mathrm{m}^{3}\right)\end{array}$} & \multirow{2}{*}{$\begin{array}{c}\text { Dynamic repose angle } \\
\left({ }^{\circ}\right)\end{array}$} & \multirow{2}{*}{ Specific gravity ${ }^{* * *}$} & \multirow{2}{*}{${ }_{(\mathrm{g})}^{1,000-\text { kernel weight }}$} \\
\hline Cultivars & $\begin{array}{l}\text { Moisture content } \\
\text { (\%, wet basis) }\end{array}$ & & & & \\
\hline \multirow{8}{*}{ Baekjjung } & 29.6 & $664.1 \pm 0.53^{\mathrm{g} 1)}$ & $54.0 \pm 0.00^{\mathrm{a}}$ & $1.2265 \pm 0.01^{\mathrm{d}}$ & $41.51 \pm 0.30^{a}$ \\
\hline & 26.2 & $670.8 \pm 0.22^{f}$ & $54.0 \pm 0.00^{\mathrm{a}}$ & $1.2380 \pm 0.01^{\mathrm{c}}$ & $41.47 \pm 0.42^{\mathrm{a}}$ \\
\hline & 22.2 & $680.7 \pm 1.93^{\mathrm{e}}$ & $54.0 \pm 0.00^{\mathrm{a}}$ & $1.2667 \pm 0.02^{\mathrm{b}}$ & $39.65 \pm 0.24^{b}$ \\
\hline & 19.3 & $693.0 \pm 1.56^{d}$ & $54.0 \pm 0.00^{\mathrm{a}}$ & $1.2723 \pm 0.01^{b}$ & $37.62 \pm 0.81^{c}$ \\
\hline & 15.5 & $742.4 \pm 0.75^{\mathrm{c}}$ & $50.0 \pm 0.00^{\mathrm{b}}$ & $1.2919 \pm 0.02^{\mathrm{a}}$ & $35.54 \pm 0.24^{d}$ \\
\hline & 13.1 & $750.1 \pm 0.65^{b}$ & $49.7 \pm 0.58^{\mathrm{b}}$ & $1.2904 \pm 0.01^{\mathrm{a}}$ & $34.98 \pm 0.50^{\mathrm{d}}$ \\
\hline & 11.0 & $751.3 \pm 0.79^{b}$ & $48.3 \pm 1.15^{\mathrm{b}}$ & $1.2974 \pm 0.02^{\mathrm{a}}$ & $32.59 \pm 0.98^{\mathrm{e}}$ \\
\hline & 9.7 & $754.0 \pm 0.33^{\mathrm{a}}$ & $46.3 \pm 1.53^{\mathrm{d}}$ & $1.2950 \pm 0.02^{\mathrm{a}}$ & $32.26 \pm 0.10^{\mathrm{e}}$ \\
\hline \multirow{8}{*}{ Jogyeong } & 28.7 & $660.0 \pm 2.05^{\mathrm{c}}$ & $54.5 \pm 0.71^{\mathrm{a}}$ & $1.2671 \pm 0.02^{f}$ & $63.07 \pm 0.30^{\mathrm{a}}$ \\
\hline & 25.6 & $665.2 \pm 1.65^{\mathrm{c}}$ & $54.5 \pm 0.71^{\mathrm{a}}$ & $1.2921 \pm 0.02^{\mathrm{e}}$ & $54.79 \pm 0.04^{b}$ \\
\hline & 23.3 & $702.9 \pm 2.14^{\mathrm{bc}}$ & $54.0 \pm 0.00^{\mathrm{a}}$ & $1.3035 \pm 0.03^{\mathrm{d}}$ & $52.89 \pm 0.34^{\mathrm{c}}$ \\
\hline & 20.8 & $752.0 \pm 2.14^{\mathrm{ab}}$ & $54.0 \pm 0.00^{\mathrm{a}}$ & $1.3125 \pm 0.02^{\mathrm{cd}}$ & $48.67 \pm 0.23^{d}$ \\
\hline & 16.5 & $754.5 \pm 1.08^{\mathrm{ab}}$ & $50.3 \pm 0.58^{\mathrm{b}}$ & $1.3242 \pm 0.03^{\mathrm{bc}}$ & $46.55 \pm 0.62^{\mathrm{e}}$ \\
\hline & 14.0 & $763.9 \pm 2.07^{\mathrm{ab}}$ & $49.0 \pm 1.00^{\mathrm{b}}$ & $1.3240 \pm 0.02^{\mathrm{bc}}$ & $45.90 \pm 0.20^{\mathrm{f}}$ \\
\hline & 11.7 & $774.2 \pm 2.40^{\mathrm{a}}$ & $47.3 \pm 1.53^{\mathrm{c}}$ & $1.3301 \pm 0.04^{\mathrm{ab}}$ & $45.52 \pm 0.10^{\mathrm{fg}}$ \\
\hline & 10.5 & $776.1 \pm 3.74^{\mathrm{a}}$ & $46.3 \pm 0.58^{\mathrm{c}}$ & $1.3379 \pm 0.02^{\mathrm{a}}$ & $45.30 \pm 0.15^{\mathrm{g}}$ \\
\hline
\end{tabular}

\footnotetext{
${ }^{*},{ }^{* *},{ }^{* * *}$ Significantly different at the $\mathrm{p}<0.05, \mathrm{p}<0.01$ and $\mathrm{p}<0.001$, respectively.
}

${ }^{1)} \mathrm{Mean} \pm \mathrm{SD}$ ( $\mathrm{n}=3$ except of bulk density:5). Means followed by the same letter in the same row are not significantly different. 
가능하였으며, 이 때 결정계수의 값은 $\mathrm{r}^{2}=0.928$ (백중), $\mathrm{r}^{2}=0.878$ (조경)로 측정되었다.

$$
\begin{aligned}
& \rho_{d}=-5.264 \mathrm{M}+809.761\left(\mathrm{r}^{2}=0.928, \text { 백중밀 }\right) \\
& \rho_{d}=-7.062 \mathrm{M}+861.530\left(\mathrm{r}^{2}=0.878, \text { 조경밀 }\right) \\
& \left(\rho_{\mathrm{d}}: \text { 산물밀도, } \mathrm{M}: \text { 함수율, } \mathrm{r}^{2}: \text { 결정계수 }\right)
\end{aligned}
$$

Tabatabaeefar(6)는 밀 함수율 $\{0$ 22\% (w.b.) $\}$ 범위에서 산 물밀도는 1 차식 $\left(\mathrm{r}^{2}=0.96\right)$ 으로 측정되었고, Karimi 등(10)은 $8,12,18 \%$ (w.b.)에서 1 차식 $\left(\mathrm{r}^{2}=0.99\right)$ 로 보고되었으며, Majdi과 Taha(18)는 함수율범위 $\{9.3 \sim 41.5 \%$ (w.b.) $\}$ 내에서 1 차식 $\left(\mathrm{r}^{2}=0.98\right)$ 로 나타내었다. 한편, 측정한 함수율 $11.0 \%$ 및 $11.7 \%$ 인 백중 및 조경의 산물밀도는 각각 $751.3 \mathrm{~kg} / \mathrm{m}^{3}$ 및 $774.2 \mathrm{~kg} / \mathrm{m}^{3}$ 이었는데, 이 값은 Mohesnin(7)이 함수율 $11.9 \%$ 밀의 산물밀도를 측정한 결과 $767 \mathrm{~kg} / \mathrm{m}^{3}$ 로 측정되어 본 연구에서 측정한 산물밀도는 선행연구와 유사하였다. Carman(21), Dutta 등(23), Gupta과 Prakash(22), Shepered과 Bhardwaj(29) 및 Mohesnin 등(7)의 보고 또한 유사한 경향 을 나타내었다.

백중 및 조경밀의 동안식각은 함수율 9 30\%(w.b.) 범위 내에서 함수율이 증가할수록 백중밀의 경우 $46.3^{\circ}$ 에서 $54.0^{\circ}$ 로 증가하였고, 조경밀은 $46.3^{\circ}$ 에서 $54.5^{\circ}$ 까지 증가하 였다. 두 품종 모두 함수율 $20 \%$ (w.b.)이하의 범위에서는 서서히 증가하였지만, $20 \%$ (w.b.)이상의 함수율에서는 $54^{\circ}$ 로 거의 변화를 나타나지 않았다. 함수율 증가에 따른 동안 식각은 $p<0.001$ 수준에서 유의적인 차이를 나타내었고, 비 선형식으로 표현이 측정되었다. 이 때 결정계수는 백중 $r^{2}=0.948$ 및 조경 $r^{2}=0.979$ 로 나타났다. 그러나, 함수율 9 20\%(w.b.)내에서는 서서히 증가함을 나타내 1차식표현 이 가능할 것으로 판단된다.

$$
\begin{aligned}
& \theta s=\frac{54.752}{1+\exp \left[\frac{-(M-(-0.435))}{5.908}\right]}\left(\mathrm{r}^{2}=0.948, \text { 백중밀 }\right) \\
& \theta s=\frac{56.138}{1+\exp \left[\frac{-(M-(-1.338))}{7.787}\right]}\left(\mathrm{r}^{2}=0.979, \text { 조경밀 }\right)
\end{aligned}
$$

( $\Theta \mathrm{s}$ : 동안식각, $\mathrm{M}$ : 함수율, $\mathrm{r}^{2}$ : 결정계수)

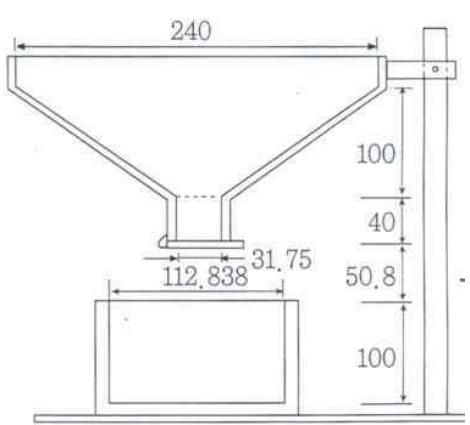

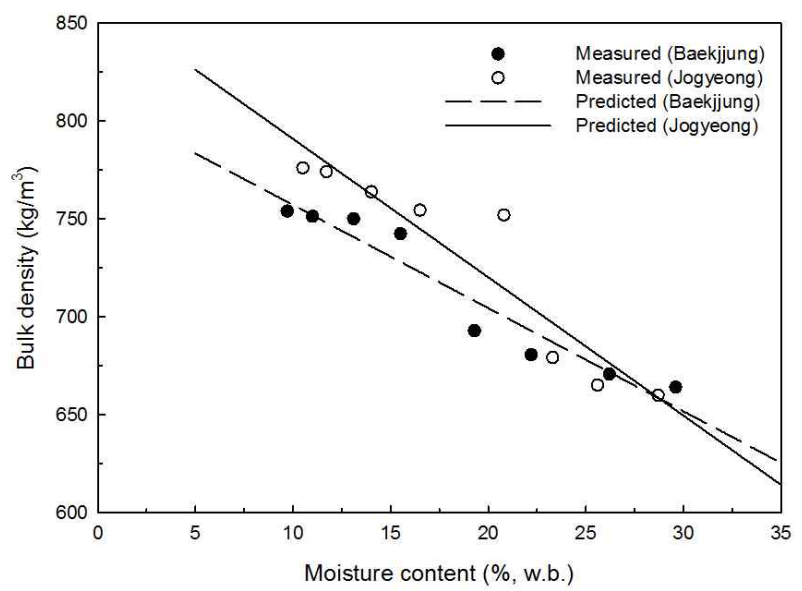

Fig. 2. Effect of moisture content on bulk density.

Tabatabaeefar(6)는 밀 함수율(0 22\%)범위에서 동안식각 은 함수율의 1 차식 $\left(\mathrm{r}^{2}=0.80\right)$ 으로 표현이 가능하다고 보고하 였으며, 벼(26), 녹두(30), 잠두콩(20), 완두콩(29) 등의 곡물 의 동안식각에 대한 측정결과에 의하면 곡물 중 밀의 동안 식각이 가장 컸으며, 다른 곡물도 함수율과 동안식각간의 상관관계가 있음을 보고하였다.

백중 및 조경밀의 비중은 함수율이 증가할수록 점차 감 소하였고, 백중밀은 1.2950 에서 1.2265 로 감소하였으며, 조 경밀은 1.3379 에서 1.2671 로 감소를 나타났다. $\mathrm{p}<0.001$ 수준 에서 함수율에 따라 비중은 유의적인 차이를 나타내었고, 1 차식으로 표현이 가능하였으며, 이 때 결정계수는 백중밀 $\mathrm{r}^{2}=0.941$ 및 조경밀 $\mathrm{r}^{2}=0.917$ 로 측정되었다.

$$
\begin{aligned}
& \mathrm{p}=-0.004 \mathrm{M}+1.339\left(\mathrm{r}^{2}=0.941, \text { 백중밀 }\right) \\
& \mathrm{p}=-0.003 \mathrm{M}+1.374\left(\mathrm{r}^{2}=0.917, \text { 조경밀 }\right) \\
& \left(\mathrm{p}: \text { 비중, } \mathrm{M}: \text { 함수율, } \mathrm{r}^{2}: \text { 결정계수 }\right)
\end{aligned}
$$

Manoher(27)의 선행연구에 따르면, 함수율범위(9 29\%) 내 비중의 값은 함수율이 점차 증가할수록 반비례적으로 감소하는 결과를 나타내어 본 연구의 결과와 유사한 경향을 보였다.

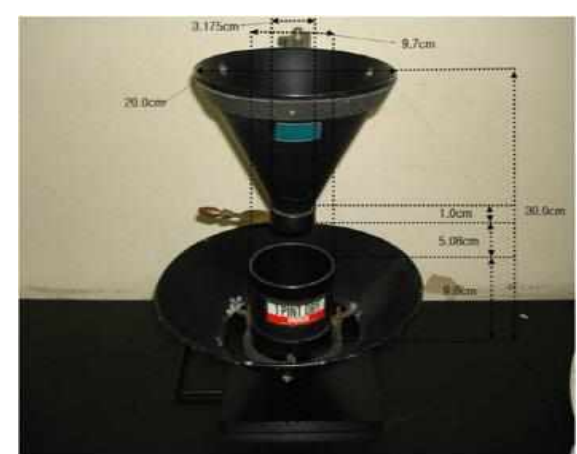

Fig. 1. Machine for bulk density (unit : mm, Seedburo). 
백중 및 조경밀의 천립중은 함수율 9 30\%(w.b.) 범위 내에서 백중밀의 경우 $32.26 \mathrm{~g}$ 에서 $41.51 \mathrm{~g}$ 로 증가하였고, 조경밀은 $45.30 \mathrm{~g}$ 에서 $63.07 \mathrm{~g}$ 로 증가하였다. 즉, 함수율이 높을수록 천립중의 값은 점차 증가하였고, $\mathrm{p}<0.001$ 수준에 서 유의적인 차이를 나타내었으며 1차식으로 표현이 가능 하였다. 결정계수는 백중밀 $\mathrm{r}^{2}=0.967$ 및 조경밀 $\mathrm{r}^{2}=0.845$ 로 측정되었다. 품종별로 유사한 함수율(조경밀 $28.7 \%$, 백중 밀 29.6\%)에서 천립중은 각각 $63.07 \mathrm{~g}$ 및 $41.51 \mathrm{~g}$ 로서 조경 밀이 백중밀보다 현저히 크게 나타났다.

$$
\begin{aligned}
& \mathrm{Wt}=0.502 \mathrm{M}+27.762\left(\mathrm{r}^{2}=0.967, \text { 백중밀 }\right) \\
& \mathrm{Wt}=0.856 \mathrm{M}+34.171\left(\mathrm{r}^{2}=0.845, \text { 조경밀 }\right) \\
& \left(\mathrm{Wt}: \text { 천립중, } \mathrm{M}: \text { 함수율, } \mathrm{r}^{2}: \text { 결정계수 }\right)
\end{aligned}
$$

Tabatabaeefar(6)는 함수율 0 22\%범위에서 천립중은 함 수율의 1 차식 $\left(\mathrm{r}^{2}=0.96\right)$ 으로 보고되었으며, 녹두(30) 30.15 $\mathrm{g}$, 완두콩(29) $75 \mathrm{~g}$, 메주콩(31) $117 \mathrm{~g}$, 이집트콩(23) 176 $\mathrm{g}$, 벼(28) 23.04 27.16 g 등 곡물 및 두류의 천립중에 관한 선행연구와 비교할 때 우리밀의 천립중은 벼 및 녹두보다는 크지만 일반적인 두류보다는 적음을 나타내었다.

함수율에 따른 장축길이, 단축길이, 두께 및 면적의 변화 함수율에 따른 백중 및 조경밀의 장축길이, 단축길이, 두께 및 면적의 변화를 살펴 본 결과는 Table 3 및 Fig.
5 8과 같다. 백중 및 조경의 장.단축길이, 두께 및 면적은 함수율이 증가할수록 그 값은 점차 증가하였다. 함수율 9 30\%(w.b.) 범위 내에서 백중밀의 장축길이는 $6.42 \mathrm{~mm}$ 에 서 $7.20 \mathrm{~mm}$ 로 조경밀의 경우 $8.71 \mathrm{~mm}$ 에서 $9.15 \mathrm{~mm}$ 로 증가 하였고, 단축길이 역시 2.90 3.49 mm(백중밀) 및 4.12 4.43 $\mathrm{mm}$ (조경밀)로 증가하였으며, 두께 2.94 3.20 mm(백중밀) 및 3.29 3.63 mm(조경밀), 면적은 14.13 19.44 mm²(백중 밀), $27.75 ~ 31.25 \mathrm{~mm}^{2}$ (조경밀)로 각각 증가하였음을 나타 내었다. $\mathrm{p}<0.001$ 수준에서 함수율의 증가에 따라 기하학적 특성은 유의적인 차이를 나타났고, 1 차식의 표현으로 나타

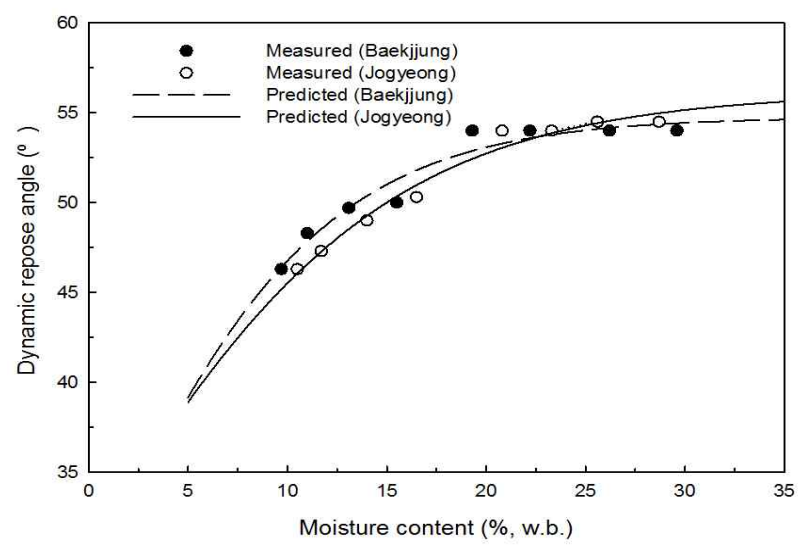

\begin{tabular}{|c|c|c|c|c|c|}
\hline \multicolumn{2}{|c|}{ Contents } & \multirow[b]{2}{*}{ Length $^{* * *}(\mathrm{~mm})$} & \multirow[b]{2}{*}{ Width $^{* * *}(\mathrm{~mm})$} & \multirow[b]{2}{*}{ Thickness $^{* * *}(\mathrm{~mm})$} & \multirow[b]{2}{*}{ Area $^{* * *}\left(\mathrm{~mm}^{2}\right)$} \\
\hline Cultivars & $\begin{array}{l}\text { Moisture content } \\
\text { (\%, wet basis) }\end{array}$ & & & & \\
\hline \multirow{8}{*}{ Baekjjung } & 29.6 & $7.20 \pm 0.25^{\mathrm{al})}$ & $3.49 \pm 0.24^{\mathrm{a}}$ & $3.20 \pm 0.13^{\mathrm{a}}$ & $19.44 \pm 1.52^{\mathrm{a}}$ \\
\hline & 26.2 & $7.08 \pm 0.34^{\mathrm{a}}$ & $3.38 \pm 0.22^{\mathrm{a}}$ & $3.18 \pm 0.13^{\mathrm{a}}$ & $18.38 \pm 1.75^{\mathrm{b}}$ \\
\hline & 22.2 & $6.80 \pm 0.36^{\mathrm{b}}$ & $3.28 \pm 0.39^{b}$ & $3.17 \pm 0.17^{\mathrm{a}}$ & $17.09 \pm 2.23^{\mathrm{c}}$ \\
\hline & 19.3 & $6.66 \pm 0.52^{\mathrm{c}}$ & $3.18 \pm 0.21^{\mathrm{c}}$ & $3.08 \pm 0.17^{b}$ & $16.39 \pm 1.56^{\mathrm{d}}$ \\
\hline & 15.5 & $6.51 \pm 0.45^{\mathrm{d}}$ & $3.00 \pm 0.14^{\mathrm{d}}$ & $3.02 \pm 0.17^{\mathrm{c}}$ & $14.74 \pm 1.07^{\mathrm{e}}$ \\
\hline & 13.1 & $6.50 \pm 0.28^{d}$ & $3.01 \pm 0.15^{\mathrm{d}}$ & $3.01 \pm 0.15^{\mathrm{c}}$ & $14.84 \pm 1.17^{\mathrm{e}}$ \\
\hline & 11.0 & $6.42 \pm 0.43^{d}$ & $2.96 \pm 0.14^{\mathrm{de}}$ & $2.99 \pm 0.15^{\mathrm{cd}}$ & $14.47 \pm 1.04^{\mathrm{ef}}$ \\
\hline & 9.7 & $6.42 \pm 0.40^{\mathrm{d}}$ & $2.90 \pm 0.17^{\mathrm{e}}$ & $2.94 \pm 0.18^{\mathrm{d}}$ & $14.13 \pm 1.11^{\mathrm{f}}$ \\
\hline \multirow{8}{*}{ Jogyeong } & 28.7 & $9.15 \pm 0.44^{\mathrm{a}}$ & $4.43 \pm 0.30^{\mathrm{a}}$ & $3.63 \pm 0.15^{\mathrm{a}}$ & $31.25 \pm 3.40^{\mathrm{a}}$ \\
\hline & 25.6 & $9.14 \pm 0.38^{\mathrm{a}}$ & $4.33 \pm 0.27^{b}$ & $3.58 \pm 0.13^{b}$ & $30.47 \pm 2.98^{\mathrm{ab}}$ \\
\hline & 23.3 & $9.15 \pm 0.70^{\mathrm{a}}$ & $4.26 \pm 0.39^{b c}$ & $3.57 \pm 0.16^{b}$ & $30.25 \pm 4.39^{b c}$ \\
\hline & 20.8 & $9.11 \pm 0.38^{\mathrm{a}}$ & $4.26 \pm 0.25^{\mathrm{bc}}$ & $3.51 \pm 0.13^{\mathrm{c}}$ & $30.04 \pm 2.57^{\mathrm{bc}}$ \\
\hline & 16.5 & $9.00 \pm 0.32^{\mathrm{a}}$ & $4.22 \pm 0.20^{c}$ & $3.46 \pm 0.14^{\mathrm{d}}$ & $29.34 \pm 1.88^{\mathrm{c}}$ \\
\hline & 14.0 & $8.73 \pm 0.42^{b}$ & $4.20 \pm 0.21^{\mathrm{c}}$ & $3.44 \pm 0.14^{\mathrm{d}}$ & $28.36 \pm 2.26^{\mathrm{d}}$ \\
\hline & 11.7 & $8.73 \pm 0.28^{b}$ & $4.21 \pm 0.20^{c}$ & $3.30 \pm 0.14^{\mathrm{e}}$ & $28.46 \pm 1.91^{\mathrm{d}}$ \\
\hline & 10.5 & $8.71 \pm 0.34^{b}$ & $4.12 \pm 0.18^{d}$ & $3.29 \pm 0.14^{\mathrm{e}}$ & $27.75 \pm 1.82^{\mathrm{d}}$ \\
\hline
\end{tabular}

Fig. 3. Effect of moisture content on dynamic repose angle.

Table 3. Geometric properties of wheat with respect to moisture content

\footnotetext{
${ }^{*},{ }^{* *},{ }^{* * *}$ Significantly different at the $\mathrm{p}<0.05, \mathrm{p}<0.01$ and $\mathrm{p}<0.001$, respectively.
}

${ }^{1)} \mathrm{Mean} \pm \mathrm{SD}(\mathrm{n}=5)$. Means followed by the same letter in the same row are not significantly different. 


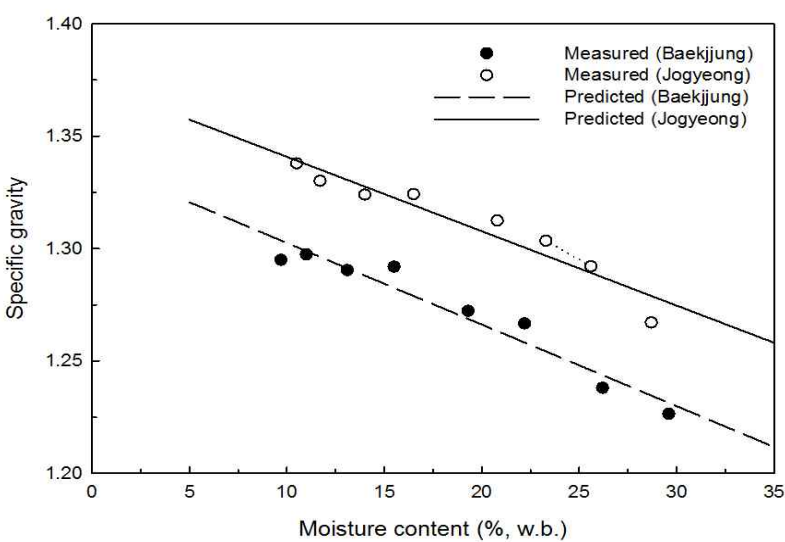

Fig. 4. Effect of moisture content on specific gravity.

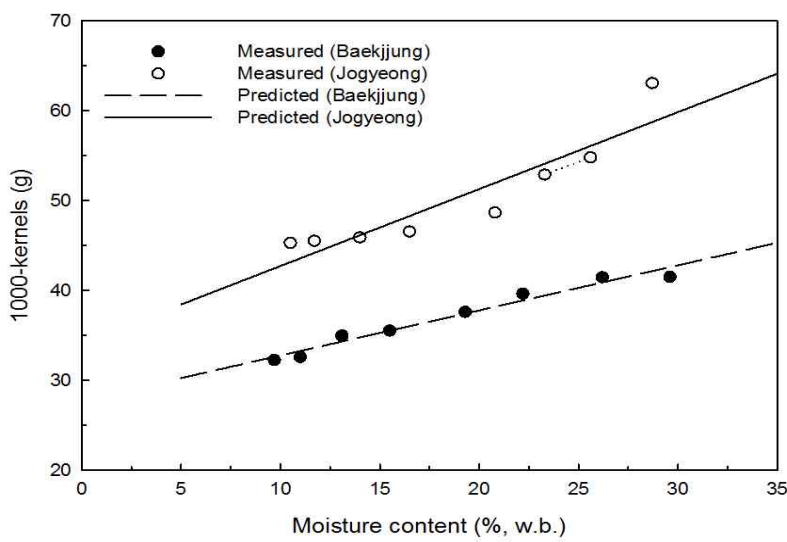

Fig. 5. Effect of moisture content on 1,000-kernel weight.

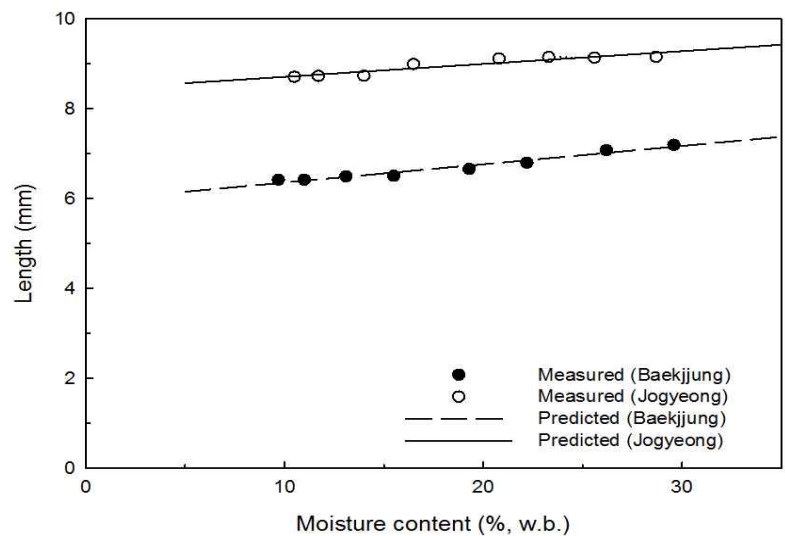

Fig. 6. Effect of moisture content on length.

내었다. 이 때 백중밀의 결정계수는 $\mathrm{r}^{2}=0.959$ (장축길이), $\mathrm{r}^{2}=0.981$ (단축길이), $\mathrm{r}^{2}=0.950$ (두께), $\mathrm{r}^{2}=0.975$ (면적) 및 조경 밀 은 $\mathrm{r}^{2}=0.863$ (장축길이), $\mathrm{r}^{2}=0.865$ (단축길이), $\mathrm{r}^{2}=0.931$ (두 께), $\mathrm{r}^{2}=0.965$ (면적)로 각각 측정되었다.

Al-Mahasneh와 Rababah(18)에 따르면, 함수율 범위 내

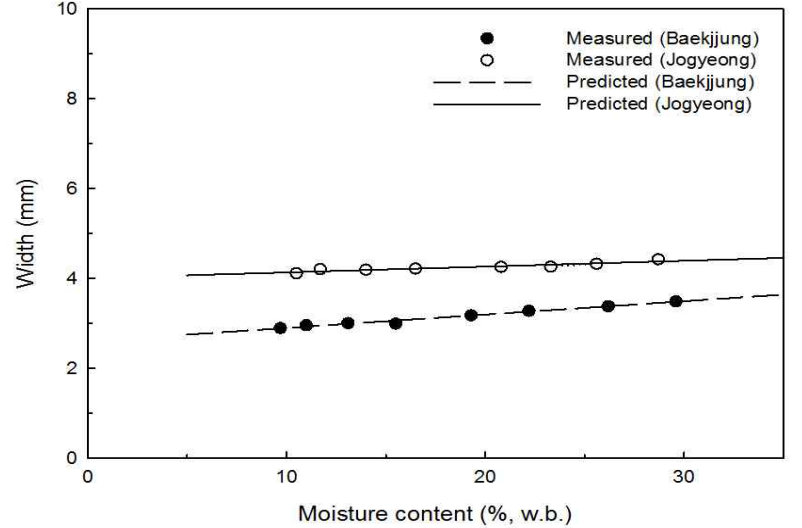

Fig. 7. Effect of moisture content on width.

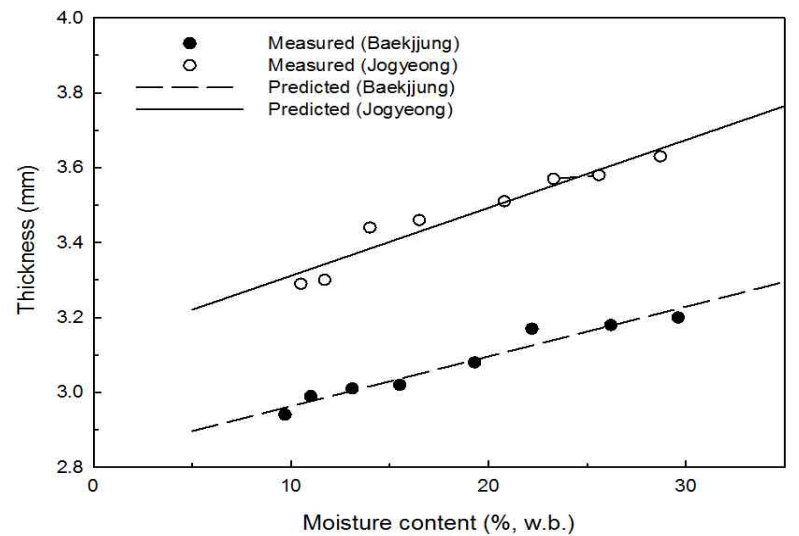

Fig. 8. Effect of moisture content on thickness.

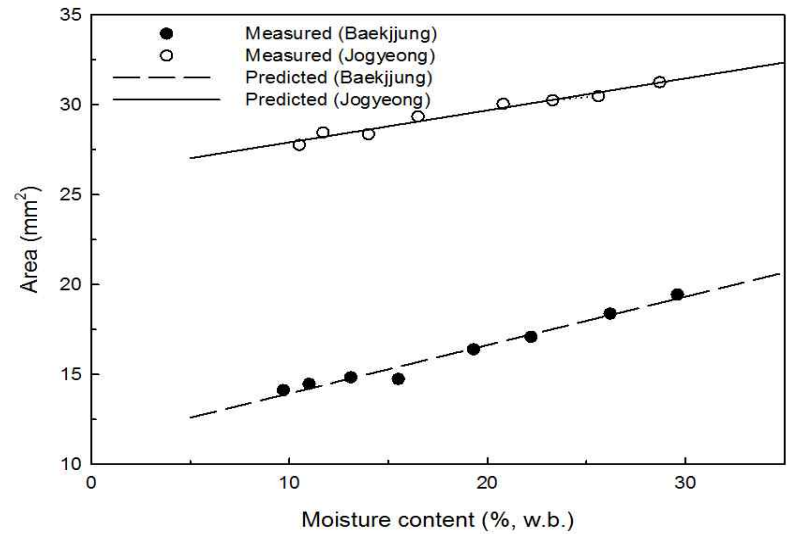

Fig. 9. Effect of moisture content on area.

(9.3 41.5\%(w.b.))에서 결정계수의 값은 $\mathrm{r}^{2}=0.941$ (장축길 이), $\mathrm{r}^{2}=0.955$ (단축길이), $\mathrm{r}^{2}=0.919$ (두께)로 보고되었다. 타 곡물로는 헤이즐넛(32), 유채씨(33), 대두(34) 및 벼(28) 등 에 대해서도 장축길이, 단축길이 및 두께는 함수율 증가에 따라 1 차식으로 표현이 가능하다고 보고하였다. 


$$
\begin{aligned}
& \mathrm{L}=0.041 \mathrm{M}+5.950\left(\mathrm{r}^{2}=0.959, \text { 백중밀 }\right) \\
& \mathrm{L}=0.029 \mathrm{M}+8.427\left(\mathrm{r}^{2}=0.863, \text { 조경밀 }\right) \\
& \mathrm{W}=0.030 \mathrm{M}+2.604\left(\mathrm{r}^{2}=0.981, \text { 백중밀 }\right) \\
& \mathrm{W}=0.013 \mathrm{M}+4.008\left(\mathrm{r}^{2}=0.865, \text { 조경밀 }\right) \\
& \mathrm{T}=0.013 \mathrm{M}+2.831\left(\mathrm{r}^{2}=0.950, \text { 백중밀 }\right) \\
& \mathrm{T}=0.018 \mathrm{M}+3.130\left(\mathrm{r}^{2}=0.931, \text { 조경밀 }\right) \\
& \mathrm{A}=0.269 \mathrm{M}+11.253\left(\mathrm{r}^{2}=0.975, \text { 백중밀 }\right) \\
& \mathrm{A}=0.178 \mathrm{M}+26.136\left(\mathrm{r}^{2}=0.965, \text { 조경밀 }\right) \\
& (\mathrm{L}: \text { 장축길이, } \mathrm{W}: \text { 단축길이, } \mathrm{T}: \text { 두께, } \\
& \left.\mathrm{A}: \text { 면적, } \mathrm{M}: \text { 함수율, } \mathrm{r}^{2}: \text { 결정계수 }\right)
\end{aligned}
$$

\section{요 약}

본 연구는 국내원맥 중 백중밀 및 조경밀의 함수율 9 30\%(w.b.) 범위내에서의 물리적 특징 중 산물밀도, 동안 식각, 비중, 천립중, 장축길이, 단축길이, 두께 및 면적을 분석하여 함수율간의 상관관계를 구명함으로써 국내밀의 체계적인 수확 후 관리 중 정선, 선별, 이송, 저장 및 가공 공정에서의 설계공정 및 기초자료로 활용하고자 연구하였 다. 함수율 9 30\%(w.b.) 범위내에서의 백중 및 조경밀의 산물밀도는 함수율이 증가할수록 서서히 감소하였으며, 백 중밀은 $754 \mathrm{~kg} / \mathrm{m}^{3}$ 에서 $664 \mathrm{~kg} / \mathrm{m}^{3}$ 로 감소하였고, 조경밀은 $776.1 \mathrm{~kg} / \mathrm{m}^{3}$ 에서 $660.0 \mathrm{~kg} / \mathrm{m}^{3}$ 로 감소하였다. 비중 또한 함수 율이 증가할수록 서서히 감소하였으며, 백중밀의 경우 1.2950 에서 1.2265 로 조경밀은 1.3379 에서 1.2671 로 측정되 었다. 반면에 천립중 및 동안식각은 함수율이 증가할수록 점차 증가하였으며, 동안식각은 함수율 $20 \%$ (w.b.)이상부 터는 거의 변화가 없었다. 천립중은 백중밀보다 조경밀이 크게 측정되었으며 그 값은 $32.26 ~ 41.51 \mathrm{~g}$ (백중밀) 및 $45.30 \sim 63.07 \mathrm{~g}$ (조경밀)로 조경밀이 현저히 크게 측정되었 다. 함수율에 따른 장축길이, 단축길이, 두께 및 면적은 함수 율이 증가할수록 점차 증가하였다. 백중밀의 장축길이는 $6.42 \mathrm{~mm}$ 에서 $7.20 \mathrm{~mm}$ 로 조경밀은 $8.71 \mathrm{~mm}$ 에서 $9.15 \mathrm{~mm}$ 로 증가하였고, 단축길이 역시 2.90 3.49 mm(백중밀) 및 4.12 4.43 mm(조경밀)으로 증가하였으며, 두께 2.94 3.20 $\mathrm{mm}$ (백중밀) 및 3.29 3.63 mm(조경밀), 면적은 14.13 19.44 $\mathrm{mm}^{2}$ (백중밀), $27.75 ~ 31.25 \mathrm{~mm}^{2}$ (조경밀)로 각각 측정되었 다. 이로써 함수율에 따른 우리밀의 물리적 특징이 구명되 었으며, 이는 우리밀에 적합한 건조저장시설 및 수확 후 관리모델 개발에 도움이 될 것으로 판단된다.

\section{감사의 글}

본 연구는 농림수산식품부 농림수산식품기술기획평가
원의 연구과제로 이루어진 연구결과의 일부이며 국내산 고수분밀을 제공해 주신 한국우리밀농업협동조합 및 합천 우리밀영농조합에 감사드립니다.

\section{References}

1. Wrigley CW (2009) Wheat: A unique grain for the world, Chemistry and technology. 4th ed, Food Science Australia and Wheat CRC, North Ryde (Sydney), NSW, Australia, p 1-17

2. KREI (2015) April 2015 USDA The world grain supply prospect. Korea rural economic institute. http://grains.krei.re. kr/board/month_market/view/wr_id/2332/page/1

3. MAFRA (2014) Agriculture, food and rural affairs statistics yearbook. Ministry of agriculture, food and rural affairs republic of Korea, Sejong, Korea, p 97-99

4. Markowski M, Zuk-Golaszewska K, Kwiatkowski D (2013) Influence of variety on selected physical and mechanical properties of wheat. Ind Crop Prod, 47, 113-117

5. Gursoy S, Guzel E (2010) Determination of physical properties of some agricultural grains. Res J Applied Sci Eng Technol, 2, 492-498

6. Tabatabaeefar A (2003) Moisture-dependent physical properties of wheat. Int Agrophysics, 17, 207-211

7. Mohsenin NN (1986) Physical properties of plant and animal materials. Gordon and Breach Science Publishers, New York, USA, p 79

8. Sahay KM, Singh KK (1994) Unit operations of agricultural processing. 1st Ed. Vikas Publishing House Pvt. Ltd., New Delhi, India, p 6

9. Chang CS (1988) Porosity and density of grain kernels. Cereal Chem, 65, 13

10. Karimi M, Kheiralipour K, Tabatabaeefar A, Khoubakht GM, Naderi M, Heidarbeigi K (2009) The effect of moisture content on physical properties of wheat. Pakistan J Nutr, 8, 90-95

11. Park NK, Lee SY, Hur HS, Jeong HS, Lee MY, Chung MJ (1999) Variation of physico-chemical and milling characteristics in some wheat varieties. Korean J Breed, 31, 160-167

12. Kang CS, Park KS, Park JC, Kim HS, Cheong YK (2008) Flour and end-use quality of "Charmdlerak" wheat, a Korean wheat. Korean J Food Preserv, 15, 219-224

13. Chang HG, Kim JY (2004) Physicochemical characteristics and sugar-snap cookie potentialities of Korean wheats. 
Korean J Food Sci Technol, 36, 754-760

14. Song JC, Lee SY, Park NK, Hur HS, Nam JH (1998) Comparisom of flour quality between domestic and imported wheat flour. Korean J Breed, 30, 156-161

15. Lee SY, Hur HS, Song JC, Park NK, Chung WK, Nam JH, Chang HG (1997) Comparison of noodle-related characteristics of domestic and imported wheat. Korean J Food Sci Technol, 29, 44-50

16. Koh BK (1999) A comparisom of protein characteristics of Korean and imported wheat varieties. Korean J Food Sci Technol, 31, 586-592

17. Kim KH, Kang CS, Seo YW, Woo SH, Heo MR, Choo BK, Lee CK, Park KG, Park CS (2013) Current regional cultural situation and evaluation of grain characteristics of Korean wheat. П. Grain characteristics collected in domestic wheat cultivar grown in Korea. Korean J Crop Sci, 58, 239-252

18. Al-Mahasneh MA, Rababah TM (2007) Effect of moisture content on some physical properties of green wheat. J Food Eng, 79, 1467-1473

19. Chung DS, Converse HH (1971) Effect of moisture content on some physical properties of grain. Transactions of the ASAE, 14, 612-614, 620

20. Fraser BM, Verma SS, Muir WE (1978) Some physical properties of faba beans. J Agric Eng Res, 23, 53-57

21. Carman K (1996) Some physical properties of lentil seeds. J Agric Eng Res, 63, 87-92

22. Gupta RK, Prakash S (1990) Effect of moisture content on some engineering properties of pulses. Paper presented at XXVI Annual Convention of Indian Society of Agricultural Engineers, February 7-9, Hissar, India

23. Dutta SK, Nema VK, Bhardwaj RK (1988) Physical properties of gram. J Agric Eng Res, 39, 259-268

24. ASABE Standards (2011) Standards Engineering Practices
Data. American Society of Agricultural Engineers, St Joseph MI, p 779-781

25. FGIS Handbooks (1996) Equipment handbook Chapter 5. Test weight per bushel apparatuses, U.S. Department of Agriculture Grain Inspection, Packers and Stockyards Administration, Washington DC, p 1-9

26. Kim YH, Cho YK, Han CS (1998) Measurement of the geometrical and mechanical properties for rice. J Biosyst Eng, 3, 261-268

27. Chawla MSS (1972) Engineering properties of a wheat. M.A.Sc Thesis. Punjabi university, India, p 32-35, 61-64

28. Reddy BS, Chakraverty A (2004) Physical properties of raw and parboiled paddy. Biosyst Eng, 88, 461-466

29. Shepherd H, Bhardwaj RK (1986) Moisture dependent physical properties of pigeon pea. J Agric Eng Res, 35, 227-234

30. Nimkar PM, Chattopadyay PK (2001) Some physical properties of green gram. J Agric Eng Res, 80, 183-189

31. Kulkarai SD, Bhole NG, Sawarkar SK (1993) Spatial dimensions of soya beans and their dependence on grain moisture conditions. J Agric Eng Res, 35, 227-234

32. Aydin C (2002) Physical properties of hazel nuts, PH-postharvest technology. Biosyst Eng, 82, 297-303

33. Calisar S, Ozcan M, Hacaseferogullan H, Yildiz MU (2005) A study on some physico-chemical properties of Turkey okra (Hibiscus esculenta L.) seeds. J Food Eng, 68, 73-78

34. Deshpande SD, Bal S, Ojha TP (1993) Physical properties of soyabean. J Agr Eng Res, 56, 89-98

35. Lee CK (2010) Post-harvest management for improving the quality of domestic wheat. In : Symposium of establishment of post-harvest system for improvement of Korean wheat quality. Rural Development Administration, August 31, Suwon, Korea 